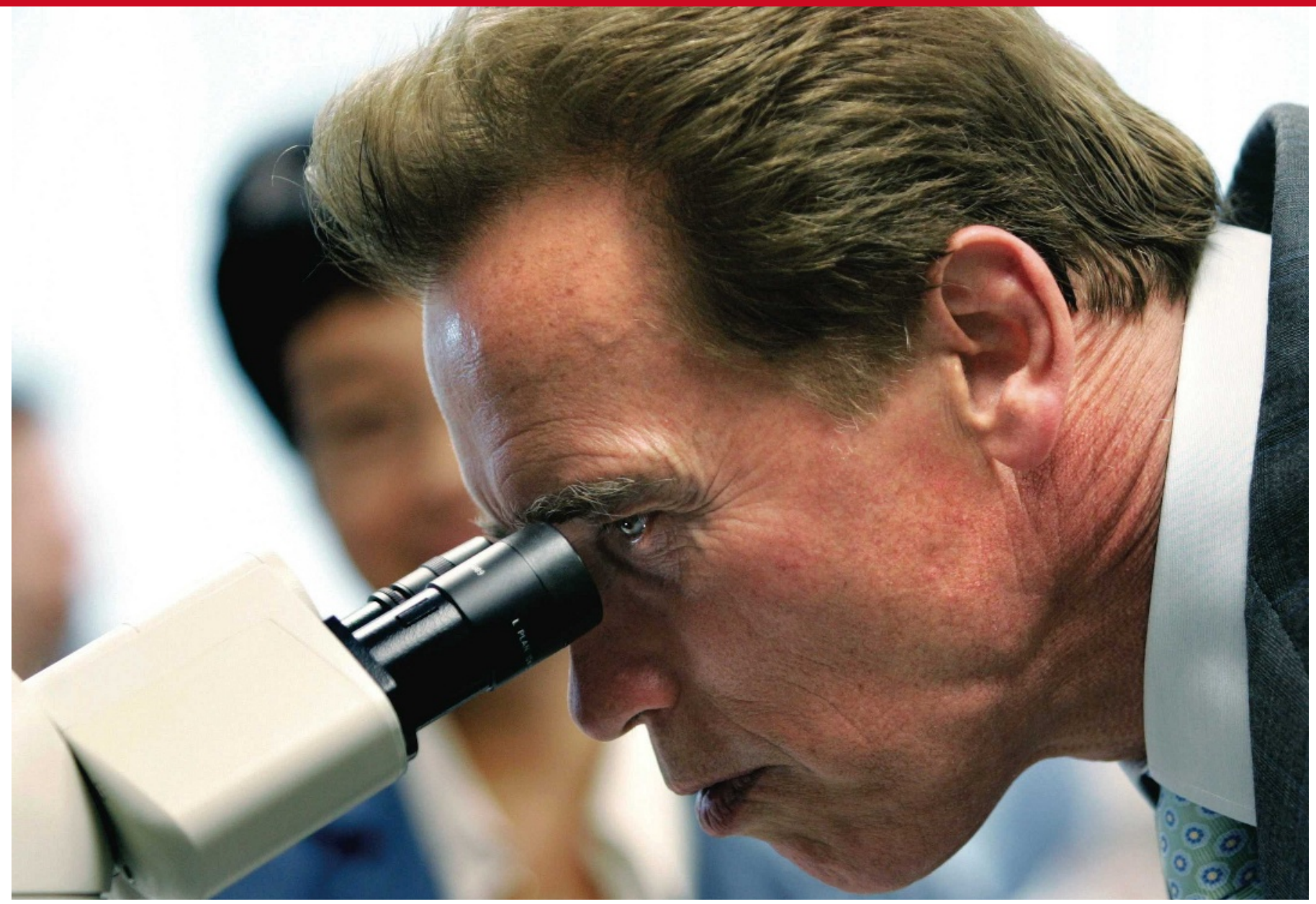

\title{
THE 3-BILLION-DOLLAR QUESTION
}

\section{Can a state do what a country cannot, and transform the way stem-cell research is funded? Erika Check Hayden reports on the California Institute for Regenerative Medicine.}

E van Snyder could hardly believe what he was hearing. About four years ago, Snyder, a neuroscientist and paediatrician, was sitting in the Los Angeles living room of Hollywood mogul Jerry Zucker, the producer and director behind movies such as Airplane! and The Naked Gun. Zucker's wife, Janet, and a mix of fellow scientists, Hollywood heavyweights, political staff and patient advocates were also there. And they were throwing around numbers that astounded Snyder, director of a stem-cell research programme at the Burnham Institute for Medical Research in La Jolla, California. Snyder had been invited to the meeting to discuss what he thought was an idea to raise US $\$ 3$ million for stem-cell research. That seemed like an enormous sum. Yet as the meeting progressed, it became clear that he had been mistaken.

"They said, 'You're missing the point - the $\$ 3$ million is to be able to get this on the ballot and get it passed for a bill that's gonna be $\$ 3$ billion,"” he says. "And I thought, I really am in la-la land now. Words like 3 billion dollars don't come out of the mouth of a scientist."

If $\$ 3$ billion seemed like a dream four years ago, it is now a reality that is changing not only the way science is done in California, but is resonating across the US biomedical landscape. Since August 2001, when President George W. Bush banned federal funding for research on human embryonic stem-cell lines created after that date, six other states have passed initiatives to fund such work using state money. But none of them is even remotely close to the scale of the California Institute for Regenerative Medicine (CIRM), the research agency brought into being after California voters passed a ballot initiative in November 2004. All the other states together have pledged just over $\$ 1$ billion for stem-cell work (see Nature 451, 622-626; 2008).

Now, after giving about $\$ 260$ million through 123 research or training grants to 22 institutions (see 'Top 10 CIRM-funded institutions', overleaf), the CIRM is about to distribute an additional \$262 million to finance a network of major buildings. Next week, its oversight committee will make final decisions on recommendations made by a working group about where the money should go. The state's universities stand to receive major boosts to their already powerful biomedical infrastructures, and have been anticipating this 'major facilities' initiative more eagerly than any other since the birth of the CIRM. But even as the agency is changing California's scientific outlook, it is also facing pressure to prove its worth to voters - and to show that it can deliver the medical and economic benefits it promised in order to convince taxpayers to fund it in the first place.

\section{Grand plans}

On an ocean bluff next door to the Salk Institute for Biological Studies in La Jolla, an eroded strip of unused road winds through a 3-hectare grove of eucalyptus trees. Overhead, seagulls fly through a chilly afternoon fog towards the shore, where paragliders are launching themselves off the edge of a cliff. If everything goes to plan, in two years the eucalyptus trees will be gone. In their place will be a 12,700-square-metre building housing 280 scientists, who will be able to look out from their lab benches and watch the gliders drift by. This site is the future home of the San Diego Consortium for Regenerative Medicine, one of seven 'CIRM institutes' likely to be awarded 
$\sum$ funding next week — and one that would not have happened without prominent local phi岸 lanthropists such as John Moores, Malin Burnham and Irwin Jacobs.

Scientific institutions have long relied on philanthropy to some extent, but the CIRM was born of their generosity. Individual donors contributed the bulk of the $\$ 26$ million in donations that backed the $\$ 35$-million campaign for Proposition 71, the ballot initiative that created the CIRM. Private donors again came to the agency's aid after the initial state bond offering to fund the agency was held up by lawsuits filed by groups opposed to stem-cell research. And in 2006, philanthropists lent the CIRM \$45 million, \$14 million of which bankrolled its first round of grants before governor Arnold Schwarzenegger (pictured, left, in research mode) came to the rescue with a $\$ 150$-million state loan. The litigation finally ended last year, freeing California to begin selling bonds.

For the imminent major facilities awards, the CIRM required institutions to come up with matching funds - which led San Diego scientists, such as Snyder and Larry Goldstein, stem-cell research director at the University of California, San Diego (UCSD), to Moores' door a few years ago. Moores, a software magnate, gave the scientists an imperative: he would give them the money to transform that eucalyptus grove next to the Salk only if they would build it together. Moores saw a joint CIRM building, housing scientists from San Diego's four premier research institutions, as something more than a monument to science; it would be a point of civic pride for San Diego.

In 2006, Moores put up $\$ 6$ million, and the San Diego Consortium for Regenerative Medicine was born, comprising UCSD, the Salk and Burnham institutes and the Scripps Research Institute. On 5 April, the CIRM's working group recommended that the consortium be awarded the agency's second-largest facility grant - $\$ 43$ million - to help build a $\$ 115$ million shared building. The consortium is an example of how California's philanthropists have become heavily involved in shaping the agency - and how scientists, in turn, have tapped into the state's private wealth.

In exchange, Californian universities have benefited enormously. The CIRM working group recommended that Stanford University in Palo Alto could receive the agency's largest facilities grant, of $\$ 47.5$ million, to build a $\$ 200$-million building it has had in the works since 2001. About 65 kilometres north, architects for the University of California, San Francisco (UCSF), designed an elegant building cascading down the face of Mount Sutro
— the hill that towers over the university's main campus - with a 'green' roof and an innovative system of split-level floors. For its bid, Stanford garnered at least $\$ 40$ million from alumnus and Business Wire founder Lorry Lokey; UCSF hauled in a \$16-million donation from Ray Dolby, founder of Dolby Laboratories, and his wife. Altogether, California institutions have committed and raised $\$ 495$ million in matching and leverage funds towards the facilities awards.

\section{Luring scientists}

When the new buildings are complete, perhaps as early as 2010, they will be stocked with some of the dozens of stem-cell scientists who have been lured to California by the CIRM. Some are high-profile hires. In 2006, Peter Donovan left Johns Hopkins University in Baltimore, Maryland, for the University of California, Irvine, and Martin Pera moved to the University of Southern California, Los Angeles, from the Monash Institute of Medical Research in Victoria, Australia. Pera's former colleague, Alan Trounson, become president of the CIRM last year. But the CIRM has also been a boon for scientists whose names are not so well-known - people such as Su Guo, a 37-year-old UCSF biologist, and a postdoctoral fellow working with her, 35-year-old Julio Ramirez.

At 9 a.m. on a Tuesday morning, Guo and Ramirez study a petri dish of mouse embryonic stem cells in a lab at San Francisco's J. David Gladstone Institutes. The space is so jammed with fume hoods, refrigerators and microscopes that there is almost no room to move around, and five other scientists, some of whom work for CIRM-funded investigators, are jostling for space around Ramirez. But he doesn't mind the crowd - he has been studying animal stem cells for only four months, and the others are helping him learn the ropes. "I can ask them anything," Ramirez says.

Before this year, Ramirez studied plant stem cells, and Guo studied brain development in zebrafish. Yet they are now working with mouse and human embryonic stem cells, thanks to a $\$ 564,000$ grant from the CIRM. Guo's grant was one of 72 that the agency gave out last February as part of the \$45-million Scientific Excellence through Exploration and Development (SEED) awards, designed to support scientists who have never worked with stem cells. With her grant, Guo hired Ramirez.

First, Ramirez will look for chemicals that have positive effects on fish brain cells that produce a neurotransmitter called dopamine. Then, he will test these drugs on human neurons derived from embryonic stem cells to see

\section{November 2004}

Proposition 71 is approved by California voters creating the \$3-billion California Institute for Regenerative Medicine (CIRM).

\section{December 2004}

Businessman Robert Klein is named chairman of the CIRM board.

\section{February 2005}

A coalition of anti-abortion and taxpayers' rights groups file lawsuits challenging the legality of Proposition 71

\section{March 2005}

Zach Hall is named interim president of the CIRM; he becomes permanent president later in the year.

\section{April 2006}

The CIRM awards its first grants: $\$ 12$ million in training grants.

\section{February 2007}

The CIRM awards its first research grants: 72 SEED grants totalling $\$ 45$ million.

\section{March 2007}

The CIRM awards 29 comprehensive research grants totalling $\$ 77$ million.

\section{April 2007}

On 17 April, Zach Hall announces that he will resign from the CIRM effective 30 April.

\section{May 2007}

Litigation against Proposition 71 ends, clearing the way for the agency to sell its first bonds; it does so in October, to the tune of $\$ 250$ million.

\section{June 2007}

The CIRM awards 17 shared research laboratory grants totalling more than $\$ 50$ million.

\section{December 2007}

The CIRM announces that board member John Reed is recusing himself from the agency's oversight committee pending a review into potential conflicts of interest. The CIRM awards $\$ 54$ million in 22 new faculty awards. Alan Trounson takes over as CIRM president.

\section{May 2008}

Decisions are expected on how $\$ 262$ million will be parcelled out in major facilities grants. 
whether they might treat symptoms of Parkinson's disease, which are caused by a dopamine deficiency. Guo has good funding support from the National Institutes of Health (NIH) - about $\$ 800,000$ a year for her zebrafish studies. But her CIRM money is letting her do something she has always wanted to do - test her work in human cells. "I always wanted my work to be applicable to patients," she says.

As Guo and Ramirez examine the cells under a microscope, there is disappointment. The day before, Ramirez had injected the cells with a plasmid - a piece of DNA - that codes for a green fluorescent protein, so today the cells should be glowing green. But they are stubbornly pale. Guo quizzes him: is he growing the cells using the right ingredients? Did he use the correct plasmid?

Culturing stem cells is sometimes more art than science, as Ramirez is discovering, and even when you follow all the rules, sometimes things still don't work. Even once Ramirez becomes expert at manipulating the cells, further obstacles could torpedo the project. "What we've proposed to do is quite daunting," Guo admits. Which raises the biggest question about the CIRM: will scientists be able to deliver the results it promised?

\section{Delivering results}

This is an urgent concern for the leaders of the CIRM, because it won the hearts of California voters by saying it would produce cures for a number of debilitating diseases. Robert Klein, the chair of the CIRM board who masterminded the campaign behind Proposition 71, has a son with diabetes. The group formed to support the proposition, Yes on 71, paid for advertisements featuring patients such as the late Christopher Reeve, who implored voters to "stand up for those who can't" from his wheelchair. That ad also referred to research done by Hans Keirstead of the University of California, Irvine, who, in the run-up to the vote, gave talks around the state featuring a video of a formerly paralysed rat walking, thanks to transplants derived from stem cells. Keirstead's advocacy drew criticism from scientists who pointed out that he hadn't published his work in a peerreviewed journal, and accused him of hyping the potential of stem-cell research. (He eventually published a paper: H. S. Keirstead et al. J. Neurosci. 25, 4694-4705; 2005.)

Klein's coalition has now morphed into a group called the Americans for Cures Foundation, whose leadership includes former CIRM staff

members and a patient advocate, Don Reed, who has a paralysed son and has lobbied heavily on behalf of the CIRM. (Reed had previously lobbied the California legislature, successfully, for money that helped fund Keirstead's experiments.) The group's stated mission is "to support fellow advocates in the fight for stem-cell research and cures".

In 2006, the CIRM adopted a strategic plan pledging to meet high expectations with numerous and specific breakthroughs within ten years - including "clinical proof-of-principle that transplanted cells derived from pluripotent cells can be used - Su Guo to restore function for at least one disease", as well as additional clinical trials of "therapies based on stem-cell research".

Yet such timelines will be difficult, if not impossible, to meet. The Tufts Center for the Study of Drug Development in Boston, Massachusetts, for example, has estimated that the average drug takes 7 years to develop, at a cost of $\$ 800$ million, whereas biotechnology products require an average of 8 years and $\$ 1.2$ billion. The CIRM has only 10 years and $\$ 3$ billion. And, unlike drugs, stem-cell therapies have not yet been shown to work in humans, so they will almost certainly require a larger investment than a typical drug. No clinical trials of treatments derived from embryonic stem cells are yet under way, but Geron, a biopharmaceutical company in Menlo Park, California, has said it will ask the US Food and Drug Administration for permission to begin the first one this year.

Further lengthening the odds, the CIRM has already been criticized for exaggerating its role

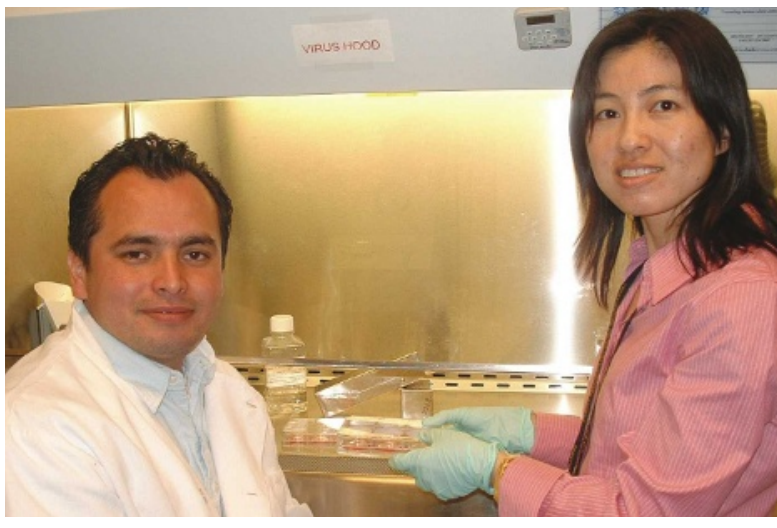

Julio Ramirez and Su Guo changed fields to work on human stem cells.
Future vision: the Institute of Regenerative Medicine at the University of California, San Francisco.

On that date, the CIRM issued a statement claiming that an agency SEED grant to one of the authors - Catriona Jamieson at UCSD - had contributed to the article, and to the clinical trial. But the article was submitted last September - the same month Jamieson received her first SEED funding cheque. Still, the CIRM stood behind its statement, explaining that one of Jamieson's postdoctoral fellows had been drawing funding from an agency training grant since July 2006, and that the SEED grant was used to help the lab perform follow-up experiments requested by reviewers. And Jamieson calls the CIRM's funding “vital and instrumental".

\section{Instrument of change}

Agency leaders are also trying to shorten and cheapen the clinical-development process. For instance, they require CIRM institute applicants to describe how they plan to move discoveries into clinical trials. And next year, the CIRM plans to award up to $\$ 20$ million per team in 'disease team research' awards, which will fund groups of researchers and doctors to try to move into clinical trials. "We have to be an instrument of change," says Trounson. "Because if every single stem-cell treatment costs $\$ 800$ million, we're just never going to get there."

The CIRM's structure is supposed to help keep it focused on cures. For instance, it gives patient advocates the power to make decisions about research right alongside scientists and businesses: on its 28-member board, 10 seats are set aside for patient advocates, 12 for Californian research institutions and universities, and 4 for businesses. But the CIRM's structure has, at times, seemed to hamper its own mission.

in research. Last month, for instance, the agency claimed credit for enabling a clinical trial to treat a group of blood cancers called myeloproliferative disorders. The trial is based on research described in an article published on 8 April (I. Geron et al. Cancer Cell 13, 321-330; 2008).
That was painfully evident at a meeting in January, when one doctor found himself begging for funding from 13 board members who were competing directly against him for money.

The doctor, Bertram Lubin, is head of the Children's Hospital Oakland Research Institute 
